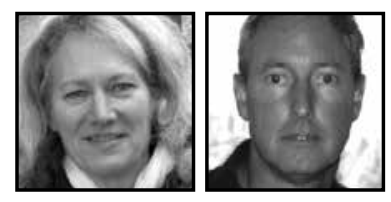

\title{
Shaping Professional Identity With Saving Stories
}

\author{
Lynne Driedger-Enns and M. Shaun Murphy \\ University of Saskatchewan
}

\section{ABSTRACT}

Concern for teachers at the beginning of their careers has been focused on retaining teachers and inducting them into fixed professional roles. This inquiry shifts the conversation to a perspective of sustaining them on the professional knowledge landscape while attending to individual identity. The experiences of one young woman named Anna opens conversation about the ways stories from her personal life shaped who she was in her classroom. This inquiry explores the need for continuity of experience as a key to continuing identity formation and sustaining teachers at the beginning of their careers.

\section{Introducing Anna as a Knowledge Holder}

Science is a challenge. What I am expected to teach in the classroom is very different from how I would naturally want to teach. If I were up north with my grandma, we would be talking about the land. Talking to me about deer-hide tanning, she would really be talking about chemistry. But it wouldn't be "now we are studying chemistry" ... no ... it's about the land. And that would be my reference ... it's how we explore. (Research conversation, Anna \& Lynne, January 21, 2011)

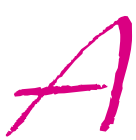

nna, the participant in this inquiry, is a woman in her second year of teaching elementary school in a western Canadian prairie province. She has a strong presence and positions herself as a knowledge holder in many ways, most often in relation to her family with many references to her grandmother. While she claimed her knowledge as a teacher, she also deeply questioned it when she came into situations of tension or uncertainty.
} 
"Am I living my personal teaching philosophy? How can I matter? What is my greater purpose for doing this work?" (Research conversation, Anna \& Lynne, December 2010 to August 2011). Her questions were wonders about who she was rather than of what she knew. At the same time, it was who she was that was what she knew.

According to Anna she was different at work than she was when she was visiting her grandmother. There was tension when she tried to integrate her familial way of learning with school expectations of learning. She expected stories that she told in her world of family to transfer into her stories about her work world of school.

One of our [familial and community based] forms of correction is making fun of people. Making fun, poking fun is part of Aboriginal world view. So that's part of who I am. It's not the world view at my school. (Research conversation, Anna \& Lynne, January 21, 2011)

When stories from her personal world, such as the models of using humor to correct a child, did not transfer into her professional world, she experienced an interruption of her story to live by, which caused her tension. These stories of tension awakened us to her experience of identity making as an early-career teacher. We listened to stories she sustained and carried between her various worlds with Clandinin and Connelly's (1998) words in mind. They wrote that identities are

narrative constructions that take shape as life unfolds and that may, as narrative constructions are wont to do, solidify into a fixed entity, an unchanging narrative construction, or they may continue to grow and change. They may even be, indeed, almost always are, multiple depending on the life situations in which one finds oneself. (p. 25)

Anna's story to live by, her identity, was not a fixed entity but a shifting one as she struggled to align the personal with the practical in a coherent life story. Anna's embodied past knowledge that shaped her in both her personal and practical worlds unfolded as she sought to establish connections between them.

When I was with my grandmother in the summers everything was integrated with everything. But it's also because of that integrating piece that school is so foreign for Aboriginal people. How do I use integration the way I know it from my grandmother into a class of thirty? What does that look like? How do I integrate life and land into cement walls with all the clocks on the walls? I tried making pemmican the other day. I don't have time or money to [do] that kind of thing every day. That comes 
out of my own pocket. But it was fun and it was a piece of life. When I am with my grandmother there isn't a document outlining the outcomes before we live them. (Research conversation, Anna \& Lynne, February 3, 2011)

Anna was trying to find coherence between the knowledge she gained in her personal life and the knowledge that the history of school mandated she implement. The need for a coherent story to live by can be understood with reference to Connelly and Clandinin's (1988) way of thinking about narrative unity, in which they explain that,

a continuum within a person's experiences ... renders life experiences meaningful through the unity they achieve for the person ... for narrative unities emerge from our past, bring about certain practices in the present, and guide us toward certain practices in our future. (p. 74)

When Anna's narrative unity was interrupted, she experienced tension, and it became apparent for Anna that "narrative unities could interweave both conflicting and competing plotlines within" (Clandinin et al., 2006, p. 154). To understand the tension she was feeling between the multiplicity of experiences in her personal and practical worlds over time called for an active reflection by which she attempted to put the whole together. According to Carr (1986), "the most striking occasions for such reflections are those radical conversions . . . in which a new view of life, of oneself, and of one's future projects requires a break with reinterpretation of one's past" (pp. 75-76). Indeed, we wondered if this was happening for Anna. She was reflecting and reinterpreting her past ideas of what it meant to be a teacher, brought to her attention by breaks in her narrative coherence. The stories of learning alongside her grandmother brought unity to this new revisioning of her professional identity. Through stories she told of her grandmother, she wove diverse experiences together in order to make sense of situations she did not understand.

\section{The Story of Beginning Teachers in Research Literature}

Much of the literature about beginning teachers focuses on a deficit understanding of their experiences - of what they lack and therefore need to attain and develop coherent stories of themselves as teachers. Multiple theories describe teacher identity and the process of learning to teach as a movement through developmental stages (Fuller \& Bown, 1975; Harrington \& Sacks, 1984; Katz, 1972). Stages are viewed as distinct experiences in a hierarchy of phases from incomplete to whole. Fuller and Bown's 
(1975) work is an example of explaining teacher identity as developmental stages. They suggested teachers moved through sequences of concern, which began with identifying with the pupil rather than as a teacher, moved to a concern for survival and a loss of their idealistic fantasy of the teaching role, then toward concern for their teaching performance, and finally into concern for pupil learning as individuals with individual needs. These concerns were suggested as universal.

Existing research has also focused on tensions with the technical aspects of learning to teach with the aim of fixing a beginning teacher's problems. Perceived problems of beginning teachers (Veenman, 1984) were expressed as issues with classroom discipline, motivating students, dealing with differences, assessing student work, relationships with parents, and inadequate teaching resources. Early-career teacher attrition has been positioned "as a problem related to individual factors of burnout, resilience, personal demographics, and personal factors" or due to "contextual factors of support, salary, professional development, collaboration, nature of the context, student issues, and teacher education" (Schaefer, Long, \& Clandinin, 2012, p. 106). Our approach as researchers to tension in an early-career teacher's life was different from previous research. Instead of perceiving problems to be smoothed over, we viewed tension as a necessary part of any new experience and realized it as indication for us to be awake and attentive to understand the experience (Clandinin, Downey, \& Huber, 2009).

The literature suggests reasons that teachers do not succeed in the first years of their teaching. As indicated previously, many "perceived problems of beginning teachers" lead to their departure from teaching-problems that beginning teachers might not be able to overcome and subsequently lead to a career shift. In our research it became clear to us that the integration of the personal with the practical was necessary to sustain teachers during the beginning of their careers (Schaefer \& Clandinin, 2011). According to Schaefer and Clandinin (2011), the shift from understanding ways we can retain teachers to ways we can sustain them in their careers is an essential shift in understanding.

\section{Understanding Identity, Narratively}

For the purposes of this research, we use the term stories to live by, a narrative term for identity developed by Connelly and Clandinin (1999), which grew from the work of Dewey (1938), Schwab (1973), Polanyi (1962), and others. From Dewey comes the turn to experience as it is framed in continuity, interaction, and situation. Schwab concentrated 
Connelly and Clandinin's attention on the curriculum commonplaces of teacher, learner, subject matter, and milieu, and Polanyi directed their study to focus on ideas of self. Connelly and Clandinin (1999) became "fascinated with trying to understand teachers as knowers: knowers of themselves, of their situations, of children, of subject matter, of teaching, of learning" (p. 1). Understanding identity became an endeavor to understand the way teachers thought, and as they explored teacher identity by listening to teachers tell stories about their experiences, they came to see teacher knowledge as a storied life composition. "These stories, these narratives of experience, are both "personalreflecting a person's life history-and social-reflecting the milieu, the contexts in which teachers live" (p. 2). They developed the narrative educational concept "personal practical knowledge" (Connelly \& Clandinin, 1988) as a way of understanding teacher knowledge, and in the process, Connelly and Clandinin (1999) began to hear teachers asking questions of identity. Questions such as, "Who am I in my story of teaching?"; "Who am I in my place in the school?"; "Who am I in children's stories?"; "Who am I in my administrators' stories?"; "Who am I in parents' stories?” (p. 3).

They found teachers asking questions in terms of "Who am I in this situation?" rather than "What do I know in this situation?" (p. 3). We heard Anna ask these same sorts of questions.

\section{Narrative Inquiry as Methodology}

Narrative inquiry (Clandinin \& Connelly, 2000) was the research methodology that shaped this project to study Anna's interactions as a beginning teacher. Foundational to this work is the assumption that

humans, individually and socially, lead storied lives. People shape their daily lives by stories of who they and others are as they interpret their past in terms of these stories. Story, in the current idiom, is a portal through which a person enters the world and by which their experience of the world is interpreted and made personally meaningful. (Connelly \& Clandinin, 2006, p. 477)

People tell stories about experiences they have lived that affect meaning making in a present situation. People also tell stories that they hope to live in the future, while simultaneously living out present experience in the shape of a story related to possible futures. We formulate future stories as plans before we live them, we live stories out in an interaction of many stories coming together, and we talk about experiences through stories after we have lived them, in an ongoing cycle. This temporal understanding of experience is one of the commonplaces of narrative inquiry (Connelly \& Clandinin, 2006). 
From a methodological perspective, narrative inquiry is a research frame appropriate to the study of early-career teacher experience because of this focus on continuity within an experiential framework. Teachers are whole persons engaged in an ongoing cycle of "living, telling, retelling, and reliving" (Clandinin \& Connelly, 2000, p. 187) across social contexts in relation to others, in relation to institutional grand narratives, and in relation to their particular professional knowledge landscapes and cultures of teaching. Narrative inquiry focused us to think of the "continuity and wholeness of an individual's life experience" (Clandinin \& Connelly, 2000, p. 20). This predisposition set the stage for us to suppose that a beginning teacher is whole and complete as he or she begins a new career, rather than carrying on traditions of developmental stages from insufficiency toward competency as research literature has suggested in the past (Fuller \& Bown, 1975; Katz, 1972; Stroot et al., 1998). Instead of observing Anna moving through a hierarchy of developmental stages toward a fixed idea of the whole teacher, we viewed her unfolding identity-her story to live by-as fluid and story based, but already whole when she stepped into the classroom.

\section{Methods}

At the heart of this narrative inquiry and research text is ethical concern for the integrity of our representations of and best interests for Anna. Our methods for hearing Anna's stories were situated in relationship over time. Throughout the two-year inquiry process, Lynne collected data through weekly research conversations that included informal talk about Anna's experiences as well as artifacts and collages that she brought with her at times to represent those experiences. One of us wrote field notes, typed transcripts of the conversations, and wrote reflections as interim texts. We met on a weekly basis to analyze field texts. As we reflected on field notes and transcripts in the writing of research texts, we saw moments when Anna was particularly animated due to particular tensions she was experiencing. We paid attention to what she was saying because of how she was saying it, and because her thoughts and responses recurred as narrative threads in research conversations, artifacts, and field notes.

Our inquiry into her stories was shaped by a three-dimensional conceptual framework. The "three commonplaces of narrative inquiry-temporality, sociality, and place-which specify dimensions of an inquiry space" (Connelly \& Clandinin, 2006, p. 479) became our analytical tool for unpacking Anna's experience. Attending to the first commonplace, we moved inward, outward, backward, and forward (Clandinin \& Connelly, 2000) in time with the stories that Anna told. We were mindful that her stories always had a past, a present, and a future. 
The second commonplace that motivated our attention was sociality. Internal conditions, such as "feelings, hopes, desires, aesthetic reactions, and moral disposition" (Connelly \& Clandinin, 2006, p. 480) were evident in the stories Anna told. Social conditions also called us to attend to the outward, external conditions around her, such as her students and professional colleagues, her family members, the culture of the institution she worked in, and other contextual factors.

The third commonplace is place. "The specific concrete, physical and topological boundaries of place" (p. 481) was key to Anna's experience on both her personal and professional knowledge landscapes. Each place she experienced on her personal landscape impacted and shaped who she was on her professional landscape.

Anna held onto particular stories as she pulled them across her experiences in her familial, personal, and professional places. We share particular tension-filled moments in this research text because of the way she told them, repeatedly, across her worlds and with passion. We came to understand these repeated tellings as saving stories.

\section{Saving Stories as a Way of Framing Experience}

Throughout our two years of research conversations Anna told stories from her family, stories about the land, and stories about Métis heritage. These recurring story threads were pulled across Anna's worlds as a way to sustain a coherent story to live by.

Shaping her narrative as a teacher were "saving stories" (King, 2003). Thomas King wrote that the stories we believe influence the outcome of life. He says some stories we tell over and over, and these are our saving stories. These stories point to beliefs and shape lives. "I tell them to myself, to my friends, sometimes to strangers. Because they make me laugh. Because they are a particular kind of story. Saving stories, if you will. Stories that help keep me alive" (p. 119).

Telling personal saving stories became an intellectual, embodied, and deeply felt way for Anna to sustain herself on the professional knowledge landscape. The repeated telling of these stories reminded her of her beliefs, and as we listened to her scaffold meaning-making possibilities (Huber \& Clandinin, 2004) for herself as a beginning teacher, we came to see how these saving stories shaped a way of understanding the personal in relation to the practical. Lopez (1990) speaks of the importance of stories as sustenance. 
The stories people tell have a way of taking care of them. If stories come to you, care for them. And learn to give them away where they are needed. Sometimes a person needs a story more than food to stay alive. That is why we put these stories in each other's memory. This is how people care for themselves. (p. 48)

The saliency of this reference is in our understanding that the stories Anna told were the stories she held in her own memory, that in her telling of them she was caring for herself. Attending to the multiplicity of Anna's stories from her personal world, we saw particular saving stories that she returned to when she found herself in the midst of tension in her professional world. We saw multiple recurring personal stories shaping her emerging professional stories. In what follows, we describe three entangled saving stories that show something of who Anna was in her personal world and who she was becoming in her professional world. We begin our unpacking of the research with attention to ways familial stories shaped her professional stories to live by.

\section{Familial Saving Stories}

Anna's passion for bringing life into subject matter on her professional knowledge landscape with children dwelt on a personal foundation where everything was in relation. This foundational way of being was nurtured by her grandmother and was a way of making sense of the world.

In the presence of my grandmother, I shift from teacher to learner. She isn't explicit in her teaching. Just because she is, she teaches. She is present. She is present in her own life. Present in relation to the land. Simply being in her presence, I am learning. (Research conversation, Anna \& Lynne, July 9, 2011)

Our view of knowledge that originates within a family comes out of the work of Huber, Murphy, and Clandinin (2011), who suggest that "familial curriculum making" is a term used to refer to the negotiated process that one grows up with as a member of a family. It is the making of a course of life that is "relationally composed in children's home and community places" (p. 2).

Referring back to the first story in this paper, we see how Anna's internal narrative about how to teach science was shaped by an experience with her grandmother as they learned about science in relation to the land that they lived on together. Learning outside, alongside her grandmother, was how she learned to explore. There was an openness to what the day presented, rather than the assertion of a prescribed set of outcomes. Tanning hides, which can be understood in a Western world view as 
chemistry, was the subject matter that positioned Anna as learner and her grandmother as teacher, and all in relation to the land in a process of exploration.

Because of this familial way of making sense, curriculum in her classroom was co-composed (Clandinin et al., 2006) in the living of relationship while still maintaining the understanding that the government curriculum document, written by others outside the classroom, was important to her work. Daily, she wrote up to four lesson plans for a particular lesson so that all the needs in her classroom aligned with government-mandated outcomes and indicators. She did this to mediate her anxiety and to fit into the institutional story. Yet, in the safety of the research space, she spoke freely about the curriculum guide as a legal document that bound her "like a ball and chain" (Research conversation, 2010). She spoke of reporting periods and standardized testing that got in the way of good teaching and learning, an understanding of teaching and learning shaped alongside her grandmother. She spoke passionately of curriculum co-composed in relationship, as her grandmother taught her, and imagined herself in relationship with the children she taught.

\section{Saving Stories About the Land}

As a young child in the midst of a life of numerous relocations, one place clearly stood out as home for her. Home was a place where she knew the contour of the land and the sound of the trees.

The only place on Earth that I consider home is up north, in northern Alberta. My grandmother's old homestead is still in the family and still when I round that bend ... ah ... that is home. I lived there for a short time. I don't remember it consciously much, but it's still home and I don't know why... just bush on either side. Evergreens ... no poplar trees ... and just peace. It's like, I'm home. (Research conversation, Anna \& Lynne, December 2010)

This personal understanding of place shaped her personal knowledge landscape, and she spoke of it frequently over time in our research conversations. When she carried the knowledge of this place into her professional world, it collided violently with rows of desks, textbooks, and institutional cement walls. Anna's saving stories tied her various personal and professional worlds together with a sense of unity and purpose.

For Anna, it made sense to her to be outside, learning in relation to the land. She returned to this story frequently in research conversations: "The closer I get to home, I feel things shedding. The closer I get to that homestead and my grandmother, I feel myself shedding Western values" (Research conversation, Anna \& Lynne, July 9, 2011). 
Situated learning experiences in nature were clearly important to Anna. However, the institutional story privileged learning that occurred within classroom walls. The walls detached her from making sense of how the world is understood through land-based experiences. Technical aspects of teaching including outcomes and indicators, rows of desks with the teacher at the front of the classroom, and the search for a textbook became her focus, and she felt pushed into a box where she shaped a professional knowledge of teaching with little reference to her personal understandings. Crites (1971) warned of abstraction and contraction as strategies of modern times. He explained that images and qualities are "detached from experience to become data for the formation of generalized principles and techniques. Such abstraction enables us to give experience a new non-narrative and a temporal coherence" (p. 308). As Anna became detached from her internal narrative that included learning outside, she felt her identity shifting toward that of a technician. In the above transcript excerpt, when she said she "felt herself shedding Western values," she is not meaning that she abandoned the technical aspects of teaching. Rather she is making space alongside the institutional story for her personal stories related to Métis heritage and her grandmother's ways. She shaped her classroom experience of teaching with the story of her grandmother's teachings in relationship to the land, and what she had learned from her grandmother about human relationships. Her grandmother's ways of teaching were based in relationship and deep respect for the person she was with. Anna created this relational sense between children and herself in the classroom.

If I am present in my teaching it comes out looking like passion but what it really is, is a deep relational sense for human beings. This passion for human beings doesn't stop at the four walls of a school. It is part of my world outside the classroom too. How can I be like my grandma in four cement walls? It's a question I ask myself each day when I am planning for my students. (Research conversation, Anna \& Lynne, July 9, 2011)

\section{Métis Heritage as Saving Story}

In Anna's classroom, a relational space for diversity was important. She honoured diverse world views of her students and was attentive to the conversations between them in their classroom curriculum making and life writing. Balancing life writing (Huber et al., 2011), both hers and the children's, with curriculum documents, was a tension for Anna.

This attention to diversity was due in part to her experience within Métis culture and a prairie province with a history of residential schools, a reservation system, and treaty 
benefits dependent on cultural status identification. Her cultural identity as a Métis woman growing up between two cultures meant she was familiar with living on the boundaries and, therefore, sensitive to issues of marginalization and belonging.

Thinking about the way the curriculum document addresses Aboriginal and Métis perspective, another mandate that is written in the curriculum guide, but in our lived curriculum we are still living racism. Then in the written document we are supposed to somehow treat this Métis perspective as part of subject matter. I have to find a way to integrate Aboriginal perspective, from these resources that represent the heartbeat of Métis peoples, find a way to "fit" it into the curriculum. How do you fit a people's heartbeat into that curriculum? And that curriculum document is part of a legalistic world. I keep hearing the voice of my administrator saying, "It's a legal document." A legal document. It cements your footing, and you are no longer mobile or fluid. How can I, [a Métis woman], belong to that? (Research conversation, Anna \& Lynne, July 2011)

She was also sensitive to the ways distinctions made an us and them border between people and what it meant to her, as a Métis person, to identify with both. Her Métis stories to live by were shaped in this understanding of life in a border culture. As Gloria Anzaldúa (1987) wrote:

Borders are set up to define the places that are safe and unsafe, to distinguish us from them. A border is a dividing line. A narrow strip along a steep edge. A borderland is a vague and undetermined place created by the emotional residue of an unnatural boundary. It is in a constant state of transition. The prohibited and forbidden are its inhabitants. (p. 25)

For Anna, this constant state of transition was sometimes represented in a story she had been telling all her life as she explained how her "restlessness" (Research conversation, Anna \& Lynne, December 2010) began with moving before Grade 1 and then often over her life as a child, youth, and young adult. This experiential story of moving shaped her feeling of restlessness as a teacher and caused her to consider leaving teaching. The telling of an exit story shaped by many transitions made her safe because she knew she could always leave.

I'm restless. I'm restless already and this is year two. I have three out of four years of a CGA, two out of three years of a B.A., one out of two years of a business admin thing. I just get sick of it or else I get enough of it so that I can get by and then I quit or get kicked out. I am seriously thinking about leaving teaching and going into medicine. (Research conversation, Anna \& Lynne, December 20, 2010) 
Anna had a strong sense of transitions - transitions from place to place, but also from story to live by to story to live by. These stories of identity continued to be told over time. She carried her saving stories of transition from her personal knowledge landscape onto the professional knowledge landscape.

Early in the research, Anna expressed a saving story out of her personal world that expressed the way she felt about being Métis.

I don't know much about that [my First Nations heritage], but I do know about being Métis. We are people stuck in the middle. We don't know who the hell we are. When you have strong Catholic roots and First Nations influence, it's a messed up, messed up scene. We are the kings and queens of identity crises, I am sure. And because of my fair skin, I get to hear how people really feel about life within diversity. [When my friends from school came to the house], I used to hide my mukluks and moccasins and was always embarrassed of my family from the north ... I'd say, "Oh, sorry, can't play!" (Research conversation, Anna \& Lynne, December 20, 2010)

In August 2011, during the summer after her third year of teaching, Anna spoke differently about what it meant to be Métis living between cultures. She was thinking about diversity in her classroom, of which she was a part, as a teacher when she said, "We grow in spaces of uncertainty. We grow when spirit or world view come into tension with uncertainty. Spaces of uncertainty draw on my Métis and spiritual identity in my life experience" (Research conversation, Anna \& Lynne, August 2011). Although she continued to tell a saving story of Métis identity, over time her perspective toward the borderlands and how she lived out that story in her classroom had changed-her professional knowledge was shifting. She no longer held a negative judgment over uncertainty and transition, but rather saw this space of tension as a growth-oriented endeavor. With her personal saving story of living as a Métis woman, a professional story of making space for diversity in school was forming.

I am Métis. I know what it is like to feel different. I have five children who identify as First Nations peoples right now in a classroom of 26. The rest are from all over the world. So when I say to my learners "you need to be careful of the choices you make for today because you might not get a chance to redo today," well in some world views that's not true. So I have to be conscious every moment of world view. World view is on the tip of my tongue always-in every subject. (Research conversation, Anna \& Lynne, January 21, 2011) 
She maintained narrative coherence through her personal and practical knowledge as she told us how "world view is on the tip of my tongue always."

Another saving story that remained fixed while shaping a professional story to live by in flux had to do with place. Her grandfather's homestead in northern Alberta shaped a learning space for her, and as she told this story of place over and over, it shaped her professional knowledge of space. She said,

There is something about four walls that isn't organic. Those walls put pressure to become quickly. Those four walls have got to go. How can you be like I am with my grandma in those four walls? They need to be dismantled. (Research conversation, Anna \& Lynne, July 2011)

In the act of claiming this knowledge about physical space from her personal life as having an impact on her professional life, a story to live by on her professional knowledge landscape shifted.

It is the story of [students'] lives that is a space of passion. This passion for human beings doesn't stop at the four walls of a school. It is outside the classroom too. Passion is presence ... a way of being in the world. (Research conversation, Anna \& Lynne, July 2011)

Saving stories helped her articulate the common thread running through her stories to live by.

Passion is to be present. That presence, that feeling between you, you know it's passion. If I am present in my teaching, it comes out looking like passion, but what it really is, is a deep relational sense for human beings. (Research conversation, Anna \& Lynne, July 2011)

Anna, in the research conversation space, was able to articulate passion as a story to live by that sustained her on her professional knowledge landscape: "Passion happens with the heart beat ... between two or more people's heartbeats. Relationships and course of life are not two-dimensional, and heartbeat sustains that multidimensional space" (Research conversation, Anna \& Lynne, July 2011).

In our work with Anna, we came to an understanding of the role of saving stories. Initially, we understood these stories as literally saving her, that in the retelling of them she maintained a coherent sense of self in relation to her shifting, uncertain, professional 
story to live by. However, as we stayed close to the idea of a saving story, we began to see them in ways that are more complex. While we still consider them a way of saving herself, we now also understand them as quite literally a story you save. This reminded us of the things we save that are important to us. The things we keep to hold again, to remind us of a moment, a place, or a person. Sometimes we intentionally take them out, like the mukluks Anna kept that were stitched by her grandmother, and sometimes we happen upon that saved thing by chance and become caught up in the memory of it.

Saving stories functioned like this for Anna. Sometimes they were stories she intentionally told to maintain a coherent narrative of herself on a new landscape-the professional knowledge landscape of teaching. Sometimes she told her saving stories because she had saved them, like one might save an artifact in a memory box (Clandinin \& Connelly, 1994). When retelling a story she had saved, she was reminding herself of another way of being, of a moment alongside her grandmother on the land.

\section{Conclusion}

We echo Thomas King's (2003) words for each of us to pay attention. We must pay attention as we walk alongside early-career teachers in hopes of sustaining them in their teaching identities.

When an early-career teacher tells us their saving stories, we remember Thomas King's (2003) words about a story when someone shares it: "You can have it if you want ... Just don't say in the years to come that you would have lived your life differently if only you had heard this story. You've heard it now" (p. 167). Now we have heard Anna's stories. What we do with them matters. All beginning teachers have saving stories. What we do with them matters.

The current learning landscape does not provide many spaces for beginning teachers to tell and understand their saving stories. Our research opens spaces for conversations about implications for new teacher in-services and pre-teacher education. The following are touchstones for teaching beginning teachers to engage as narrative inquirers into their saving stories.

In our research alongside Anna we became aware that beginning teachers need a space for conversation. Anna drew our attention to the importance of asking them who they are and where they come from. This means creating safe spaces where beginning 
teachers may tell stories of who they are and speak freely about the tensions they experience when their stories to live by collide with people and situations in school. We became conscious of the ways that experienced teachers and beginning teachers initiate relationships with each other that allow them both to play their saving stories forward into their lives in schools. We attended to how we might create an openness to learning to let go of some saving stories as beginning teachers incorporate new knowledge into their practical knowledge. This is not mandated or forced knowledge, but rather an organic moving forward in educative ways. The first years as a teacher are not something to quickly move through. Rather, let those first years be a place where we dwell in questions, and live in the midst of wonder and uncertainty in a Maxine Greene (1995) spirit of "forever on the way."

We end this manuscript with Anna's words that illustrate her experience with the research conversations.

Last time we got together I got in my car and I was singing. I haven't done that for a long time. What are all those other beginning teachers doing out there who don't have someone like you. How do they get through this? I feel like we get together and I spew it all out there and then I can walk out into my same life differently. (Research conversation, Anna \& Lynne, December 20, 2010)

\section{References}

Anzaldúa, G. (1987). Borderlands: The new mestiza: La frontera. San Francisco: Spinsters/ Aunt Lute.

Carr, D. (1986). Time, narrative, and history. Bloomington: Indiana University Press.

Clandinin, D. J., \& Connelly, F. M. (1994). Personal experience methods. In N. K. Denzin \& Y. S. Lincoln (Eds.), Handbook of qualitative research (pp. 413-427). Thousand Oaks, CA: Sage Publications.

Clandinin, D. J., \& Connelly, F. (1998). Stories to live by: Narrative understandings of school reform. Curriculum Inquiry, 28(2), 149-164.

Clandinin, D. J., \& Connelly, F. M. (2000). Narrative inquiry: Experience and story in qualitative research. San Francisco: Jossey-Bass.
Clandinin, D. J., Downey, C. A., \& Huber, J. (2009). Attending to changing landscapes: Shaping the interwoven identities of teachers and teacher educators. Asia Pacific Journal of Teacher Education, 37(2), 141-114.

Clandinin, D. J., Huber, J., Huber, M., Murphy, M. S., Pearce, M., Murray-Orr, A., et al. (2006). Composing diverse identities: Narrative inquiries into the interwoven lives of children and teachers. London: Routledge.

Connelly, F. M., \& Clandinin, D. J. (1988). Teachers as curriculum planners: Narratives of experience. New York: Teachers College Press.

Connelly, F. M., \& Clandinin, D. J. (1999). Shaping a professional identity: stories of educational practice. New York: Teachers College Press. 
Connelly, F. M., \& Clandinin, D. J. (2006). Narrative inquiry. In J. Green, G. Camilli \& P. Elmore (Eds.), Handbook of complementary methods in education research (pp.477-487). Mahwah, $\mathrm{NJ}$ : Lawrence Erlbaum.

Crites, S. (1971). The narrative quality of experience. Journal of the American Academy of Religion, 39(3), 291-311.

Dewey, J. (1938). Experience and education. New York: Touchstone.

Fuller, F., \& Bown, O. (1975). Becoming a teacher. In K. Ryan (Ed.), Teacher Education, 74th Yearbook of the National Society for the Study of Education. Part 2 (pp. 25-52). Chicago: University of Chicago Press.

Greene, M. (1995). Releasing the imagination: Essays on education, the arts, and social change. San Francisco: Jossey-Bass Publishers.

Harrington, G. N., \& Sacks, S. R. (1984). Student to teacher: Novel strategies for achieving the transition. Journal of Education for Teaching: International Research and Pedagogy, 10(2), 154-163.

Huber, J., \& Clandinin, D. J. (2004). Scaffolding children's identity making with literature. In E. R. A. Rogers (Ed.), Strategies for scaffolding literacy instruction: Strategies for K-4 classrooms (pp. 143-161). Portsmouth, NH: Heinemann Publishers.

Huber, J., Murphy, M. S., \& Clandinin, D. J. (2011). Places of curriculum making: Narrative inquiries into children's lives in motion. Bingley, UK: Emerald Group Publishing Limited.
Katz, L. G. (1972). Developmental stages of preschool teachers. The Elementary School Journal, 73(1), 50-54.

King, T. (2003). The truth about stories. Toronto, ON, Canada: House of Anansi Press Inc.

Lopez, B. (1990). Crow and weasel. San Fransisco: North Point Press.

Polanyi, M. (1962). Personal knowledge: Towards a post-critical philosophy. Chicago: University of Chicago Press.

Schaefer, L., \& Clandinin, D. J. (2011). Stories of sustaining: A narrative inquiry into the experiences of two beginning teachers. Learning Landscapes, 4(2), 275-295.

Schaefer, L., Long, J. S., \& Clandinin, D. J. (2012). Questioning the research on early career teacher attrition and retention. Alberta Journal of Educational Research, 58(1), 106-121.

Schwab, J. J. (1973). The practical 3: Translation into curriculum. The School Review, 81(4), 501-522.

Stroot, S., Keil, V., Stedman, P., Lohr, L., Faust, R., Schincariol-Randall, L., et al. (1998). Developmental stages of teachers. Peer Assistance and Review Guidebook. Columbus $\mathrm{OH}$ : Ohio Department of Education.

Veenman, S. (1984). Perceived problems of beginning teachers. Review of Educational Research, 52(2), 143-178. 


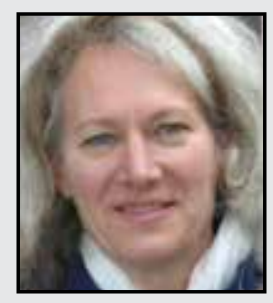

Lynne Driedger-Enns is a PhD student at the University of Saskatchewan, in the department of Curriculum Studies. Lynne is an elementary school teacher with 15 years of experience in Saskatchewan, Zimbabwe, and India. Her practice integrates the arts in relational curriculum making with children. Her research interests include identity making, familial and school curriculum making, and teacher education. This paper comes out of her interest in the significance of personal knowledge in shaping and sustaining the professional identity of beginning teachers.

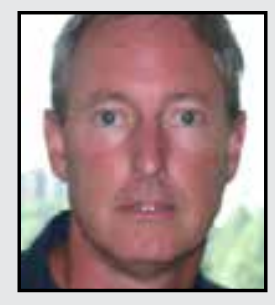

M. Shaun Murphy is an Associate Professor in the Department of Educational Foundations at the University of Saskatchewan. His research interests are based in relational narrative inquiry with a focus on familial and school curriculum making; the interwoven lives of children, families, and teachers; and teacher education. Currently, he is involved in a rural education research project considering the interwoven lives of children, families, teachers, and administrators in curriculum making. Shaun was awarded the 2012 Provost's College Award for Outstanding Teaching, University of Saskatchewan and the 2013 Early Career Award, Narrative Research Special Interest Group, American Education Research Association. 